\title{
Influence of Soil Moisture and Air Temperature on the Stability of Cytoplasmic Male Sterility (CMS) in Maize (Zea mays L.)
}

\author{
Heidrun Bueckmann, Katja Thiele, Joachim Schiemann \\ Institute for Biosafety in Plant Biotechnology, Julius Kühn-Institut, Federal Research Centre for \\ Cultivated Plants (JKI), Quedlinburg, Germany \\ Email: katja.thiele@jki.bund.de
}

Received 10 December 2015; accepted 15 February 2016; published 18 February 2016

Copyright $@ 2016$ by authors and Scientific Research Publishing Inc.

This work is licensed under the Creative Commons Attribution International License (CC BY).

http://creativecommons.org/licenses/by/4.0/

(c) () Dpen Access

\begin{abstract}
Cytoplasmic male sterility (CMS) is a maternally inherited trait that suppresses the production of viable pollen. CMS is a useful biological tool for confinement strategies to facilitate coexistence of genetically modified (GM) and non-GM crops in case where it is required. The trait is reversible and can be restored to fertility in the presence of nuclear restorer genes ( $R f$ genes) and by environmental impacts. The aim of this study was to investigate the influence of the level of irrigation on the stability of CMS maize hybrids under defined greenhouse conditions. Additionally the combination of irrigation and air temperature was studied. Three CMS maize hybrids were grown with different levels of irrigation and in different temperature regimes. Tassel characteristics, pollen production and fertility were assessed. The CMS stability was high in hot air temperatures and decreased in lower temperatures. The level of irrigation had no major effect on the level of sterility. The extent of these phenomena was depending on the genotype of CMS maize and should be known before using CMS for coexistence purposes.
\end{abstract}

\section{Keywords}

Soil Moisture, Air Temperature, Biological Confinement, Cytoplasmic Male Sterility (CMS), Genetically Modified (GM) Maize (Zea mays L.)

\section{Introduction}

Cytoplasmic male sterile (CMS) maize is proven as a reliable biological confinement method to prevent crosspollination of pollen into neighbouring fields [1]. This might be necessary if genetically modified (GM) maize is 
grown in arable areas with a high level of non-GM crops or even organic farming. Maize plants produce a huge amount of pollen [2] [3], but 95\% of this pollen does not contact the stigmatic surface of the maize silk and is deposited into the environment [4]. Several physical containment methods for maize such as isolation distances and border rows are already applicable. In regions with a wider sowing season, e.g. Spain, different sowing dates and — therefore—-different blooming periods can avoid cross-pollination [5] [6].

CMS is a maternally inherited trait that prevents the development of functional pollen [7] [8]. It results from a loss-of-function mutation in the mitochondrial genome [9] and causes a dysfunction of the respiratory metabolism and an abnormal production of male gametes [10] [11]. The plants develop no or nonvital pollen but the female fertility is not affected. Three main types of CMS are known for maize [12]: CMS-T or Texas-cytoplasm [13] [14], CMS-S or USDA-cytoplasm [15] and CMS-C or Charrua-cytoplasm [16]. Their differences are based on different restorer of fertility genes $(R f)$. Even though the determination of CMS occurs in extranuclear, these nuclear $R f$ genes can compensate the CMS effect of the cytoplasm [8]. As a result tassels can be partly restored or even become fertile with more or less vital pollen in the first-generation progeny (F1).

Irrespective of the internal interactions between mitochondrial and nuclear genes, fertility of many CMS plant species can also be restored by environmental impacts like heavy rain, extreme heat etc. [17]-[21]. As can be expected, our field studies showed that the climate had an impact on the performance of several CMS maize hybrid genotypes [1]. In a trial year with consistently lower temperatures than the longstanding mean and high precipitation rates, the growth of the maize stands was unequal and partly delayed. Later developed plants (delay of ca. 10 days) arose due to cold and wet weather conditions earlier in the season. These plants bloomed in round about $2^{\circ} \mathrm{C}$ lower temperatures and much more precipitation $(+127 \mathrm{~mm}$ above the longstanding mean for August). They developed fertile tassels with a large amount of pollen while most of the earlier flowers of the same hybrid were sterile. These observations raised the question whether the air temperature and water availability might have an impact on the CMS trait stability. The influence of air temperature on the stability of the CMS trait was already demonstrated [22], but the underlying mechanisms are not completely understood.

The aim of this study was to investigate the influence of the level of irrigation on the CMS stability of maize hybrids under defined greenhouse conditions. Additionally the interaction of irrigation with two temperature regimes was studied. The results will provide more detailed information about the applicability of CMS maize hybrids under different environmental conditions as a tool for coexistence purposes.

\section{Material and Methods}

Two experiments (experiment 1 and 2) were carried out to test the influence of irrigation on the level of sterility. In a third experiment (experiment 3 ) the interaction between irrigation level and air temperature was tested. In all experiments differentiated irrigation was applied until the end of flowering.

Experiment 1 was sown in April 2013 and flowering ended in the third quarter of July. Experiment 2 started at the beginning of September 2013. The flowering period ended beginning of November. In both experiments the air temperature was not specified. The irrigation levels of experiment 1 and 2 were: "dry", "regular" and "wet". In experiment 3 only "dry" and "wet" were tested. To ensure a correct irrigation the water content of the soil was tested every second day with a soil (PCE-SMM1, PCE Instruments, Meschede, Germany). The pots were irrigated to free soil water contents of 12\% - 18\% in "dry" conditions (just before plant decrease), 20\% - 25\% in "regular" conditions (sufficient water for plant growth) and $>50 \%$ in "wet" conditions (water saturated soil).

The experiment 3 was carried out to test possible interactions of irrigation levels and air temperatures. Two different air temperature regimes ("cold", "hot”) were applied, each in one separate greenhouse chamber (Table 1). The regime "cold" started with defined temperatures of $21^{\circ} \mathrm{C}$ at night and $25^{\circ} \mathrm{C}$ at day time to provide positive initial conditions. The temperatures were reduced stepwise to $16^{\circ} \mathrm{C}$ at night and $21^{\circ} \mathrm{C}$ at daytime. In "hot" temperature conditions sowing was performed at $15^{\circ} \mathrm{C}$ at night and $25^{\circ} \mathrm{C}$ at daytime, and temperatures were increased stepwise to reach $22^{\circ} \mathrm{C}$ at night and $35^{\circ} \mathrm{C}$ at daytime after 35 days. To control the defined temperature regimes permanent measurements of air temperature and humidity in the green house chambers were carried out.

During daytime the plants were illuminated 16 hours by 5000 Lux. Ten plants per CMS hybrid and irrigation level were cultivated in $30 \mathrm{l}$ plastic pots filled with a standard greenhouse soil based on crumble peat. The CMS maize hybrids tested in the greenhouse were previously used in field trials for testing their potential as a biological confinement tool [1]: Torres and Zidane (Kleinwanzlebener Saatzucht AG, Germany) both belong to the 
Table 1. Temperature regimes of the greenhouse experiment 3.

\begin{tabular}{ccc}
\hline Temperature regimes & Setting & Night/day \\
\hline & sowing & $21^{\circ} \mathrm{C} / 25^{\circ} \mathrm{C}$ \\
cold & after 14 days & $18^{\circ} \mathrm{C} / 25^{\circ} \mathrm{C}$ \\
& after 21 days & $16^{\circ} \mathrm{C} / 21^{\circ} \mathrm{C}$ \\
& sowing & $15^{\circ} \mathrm{C} / 20^{\circ} \mathrm{C}$ \\
hot & after 14 days & $15^{\circ} \mathrm{C} / 25^{\circ} \mathrm{C}$ \\
& after 21 days & $18^{\circ} \mathrm{C} / 28^{\circ} \mathrm{C}$ \\
& after 35 days & $22^{\circ} \mathrm{C} / 35^{\circ} \mathrm{C}$ \\
\hline
\end{tabular}

CMS-S cytoplasm and DSP2 (Delley Seeds and Plants Company, DSP, Switzerland) belongs to the CMS-T cytoplasm.

In all experiments the tassels were assessed whether they stayed sterile, were partly restored or even fertile (Figure 1). The results of the flower assessment were weighted as follows: sterile tassel $=1$; weak partly restored tassel $=2$; partly restored tassel $=3$; strong partly restored tassel $=4$; complete restored tassel $=5$. The pollen production was weighted as follows: no pollen $=1$; very few pollen $=2$; few pollen $=3$; many pollen $=4$. The values for tassel and pollen development were added and gave the value for the CMS stability ("loss of CMS”).

Pollen vitality was tested in experiment 3 . Therefore, all plants were self-pollinated by hand and developed kernels were counted. Statistics about flower assessment and kernel number per ear were done by 2-way-anova (Origin software, version 8.1, Heise, Germany).

\section{Results}

Experiment 1 and 2 were carried out in different seasons. Consequently, different air temperatures of $5^{\circ} \mathrm{C}$ on average were measured in the green house chamber from sowing until the end of flowering (not shown). The period for 14 days before and until the end of flowering is most important for the fertility of inflorescence and the maturation of pollen. In experiment 1 this period was reached in June and July. Accordingly, the air temperatures of $25^{\circ} \mathrm{C}$ on average reached up to $37^{\circ} \mathrm{C}$ maximum (Figure 2). The lowest temperature was $17^{\circ} \mathrm{C}$. In experiment 2 the flowering period was in October and November. Average temperatures were $22^{\circ} \mathrm{C}$ with a peak value of $37^{\circ} \mathrm{C}$ and the lowest temperature of $17^{\circ} \mathrm{C}$ as well.

In both irrigation experiments (experiment 1 and 2) Torres was the CMS hybrid with the highest level of sterility (Figure 3) independent of the irrigation quantity. "Loss of CMS" values were between 3.6 and 4.6 (Table 2). Compared to Torres, Zidane restored more to fertility in both experiments and reached "loss of CMS" values of 6 to 9. An impact of the irrigation level could not be detected. DSP2 expressed different levels of "loss of CMS" in experiment 1 and 2. It stayed close to sterility-similar to Torres-in experiment 1 ("Loss of CMS" values 4 - 4.8) and developed fertility ("Loss of CMS" value 9) in experiment 2, independently from irrigation. Generally, on a level of $p=0.05 \%$ the CMS maize hybrids differed significantly from each other (Table 3). Experiment 1 showed significant differences between Zidane and Torres as well as DSP2. In experiment 2 all three CMS maize hybrids showed significant differences of the stability level at $p=0.05 \%$.

Experiment 3 was more complex depending on the defined temperature regimes (Table 1). The temperature measurements during the experiment (Figure 4) showed a minimal deviation of $\pm 1^{\circ} \mathrm{C}$ from the temperature defined. In the variant "hot" the average temperature was $27^{\circ} \mathrm{C}$ with a maximum of $37^{\circ} \mathrm{C}$ and a minimum of $17^{\circ} \mathrm{C}$. The variant "cold" had an average temperature of $19^{\circ} \mathrm{C}$ with maximum and minimum temperatures of $37^{\circ} \mathrm{C}$ and $15^{\circ} \mathrm{C}$, respectively.

The CMS maize hybrid DSP2 stayed completely sterile in hot temperature conditions (Figure 5-value 2). In a cold environment all plants were fertile (value 9). The results were independent from the irrigation level (Figure 5, Table 4). Torres stayed nearly sterile in hot temperatures $\left(22^{\circ} \mathrm{C} / 35^{\circ} \mathrm{C}\right.$ - "Loss of CMS" value 2.4 and 2.5). Some plants developed a very low amount of anthers which produced nearly no pollen or even stayed sterile. In low temperatures a few plants restored to fertility and developed some anthers which shed a small amount 


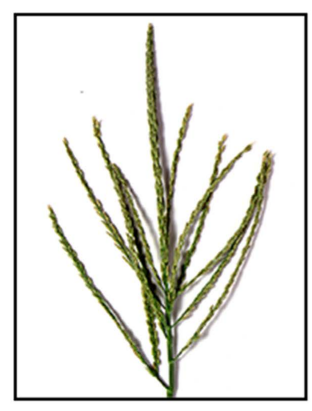

sterile tassel

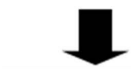

no pollen

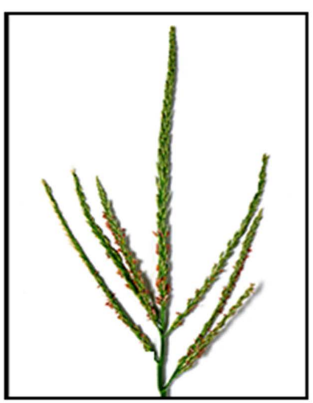

partly restored tassel

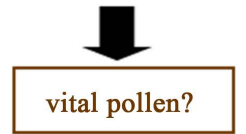

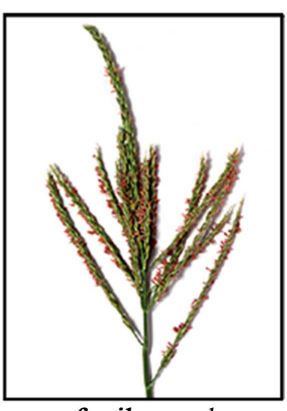

fertile tassel

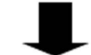

fertile pollen?

Figure 1. Tassel characteristics of CMS maize plants.

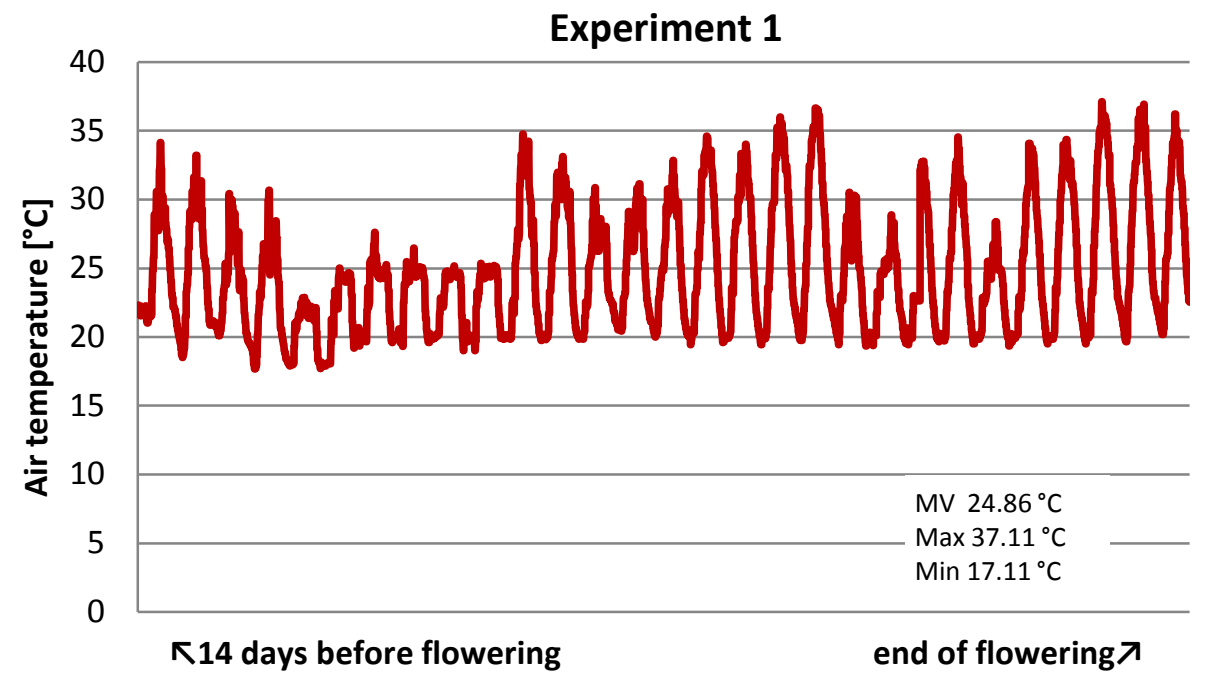

(a)

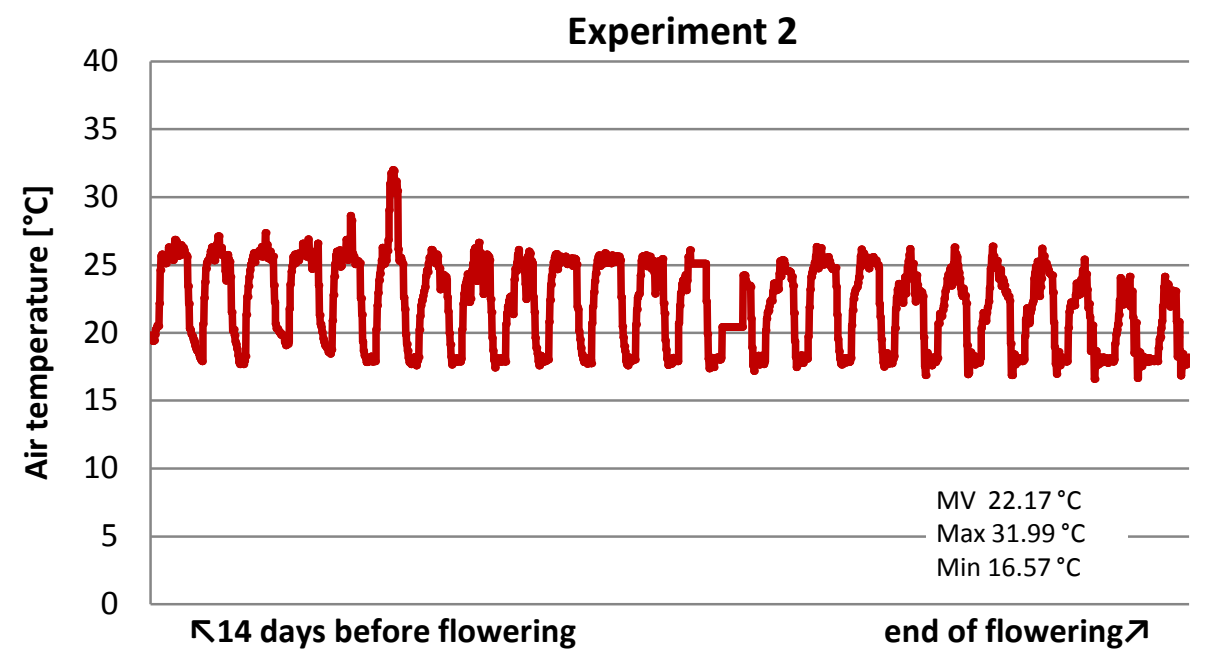

(b)

Figure 2. Air temperatures in Experiment 1 and 2 from 14 days before flowering until the end of flowering. 


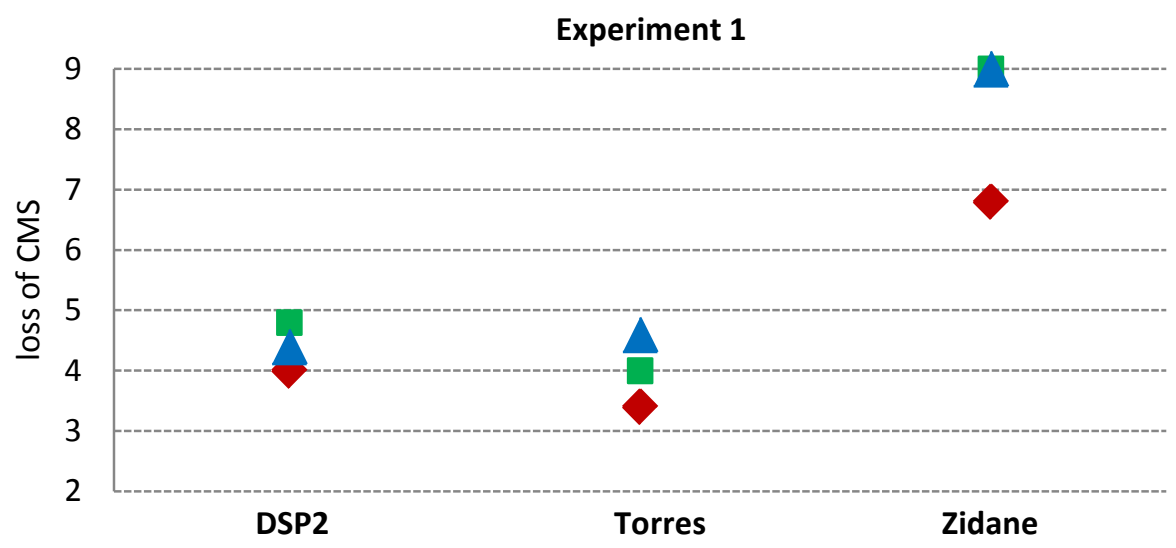

CMS: 2 = sterile, 9 = fertile

$\diamond$ dry regular $\Delta$ wet

(a)

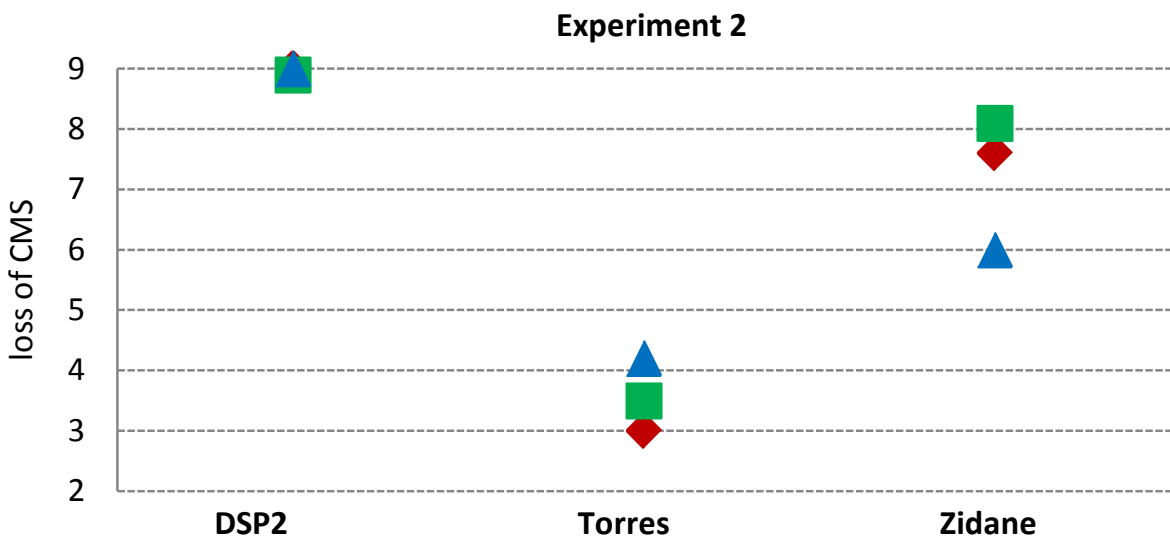

CMS: 2 = sterile, 9 = fertile

$\diamond$ dry regular $\Delta$ wet

(b)

Figure 3. Stability of the sterility trait of three CMS maize hybrids in dependence of irrigation level in Experiment 1 and 2.

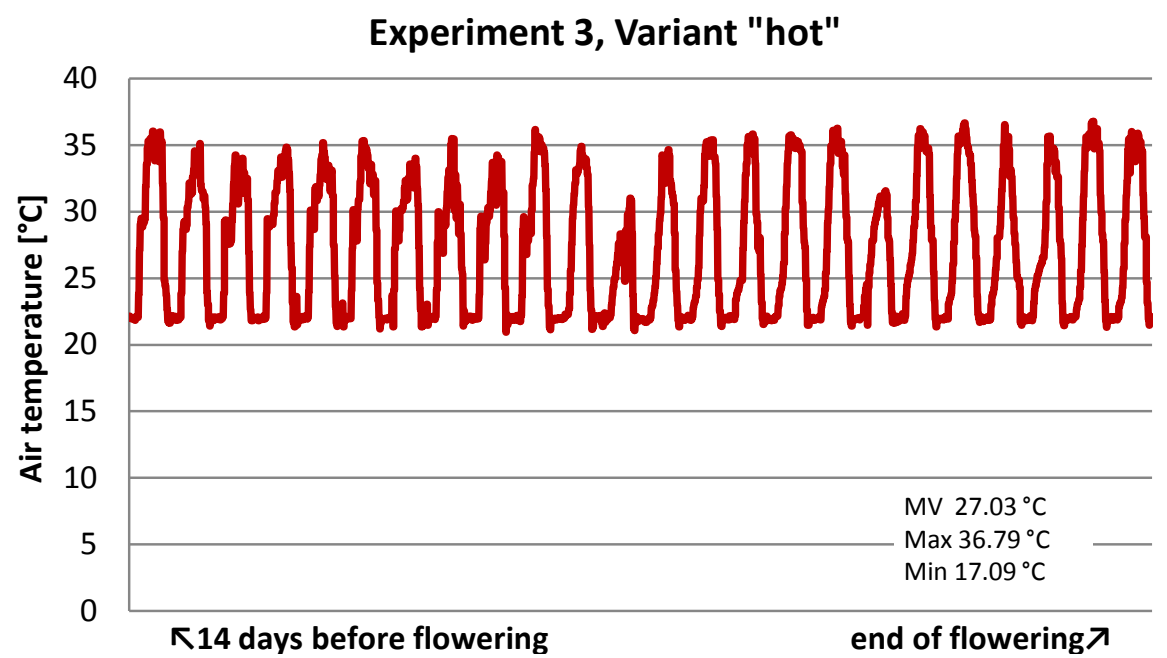

(a) 


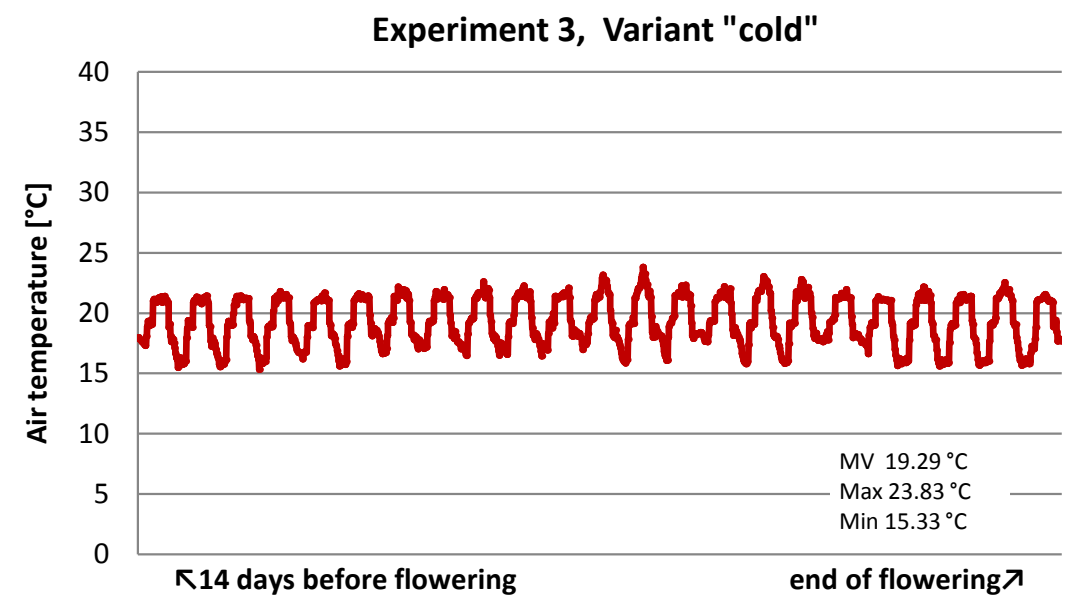

(b)

Figure 4. Measured air temperatures in variant "hot" and "cold" from 14 days before flowering until the end of flowering-Experiment 3.

Table 2. Loss of the stability of CMS and standard deviations of three CMS maize hybrids in different irrigation levels-Experiment 1 and 2 .

\begin{tabular}{cccc}
\hline Experiment 1 Irrigation level & DSP2 & Torres & Zidane \\
\hline dry & 4.0 & 3.4 & 6.8 \\
Standard deviation & 1.76 & 0.97 & 1.23 \\
regular & 4.8 & 4.0 & 9.0 \\
Standard deviation & 1.93 & 0.00 & 0.00 \\
wet & 4.4 & 4.6 & 9.0 \\
Standard deviation & 2.07 & 0.97 & 0.00 \\
\hline Experiment 2 Irrigation level & & & Zidane \\
\hline dry & DSP2 & Torres & 7.6 \\
Standard deviation & 9.0 & 3.0 & 0.84 \\
regular & 0.00 & 0.00 & 8.1 \\
Standard deviation & 8.9 & 3.5 & 0.32 \\
wet & 0.32 & 0.71 & 6.0 \\
Standard deviation & 9.0 & 4.2 & 0.94 \\
\hline
\end{tabular}

2 = sterile, 9 = fertile.

Table 3. Significance of irrigation level and genotype influences on the level of stability of the CMS trait, 2-way anova, $p=$ 0.05 (Experiment 1 and 2). Different letters mark significant differences.

\begin{tabular}{|c|c|c|c|}
\hline \multirow[t]{2}{*}{ Experiment 1} & \multicolumn{3}{|c|}{ Significance level $p=0.05$} \\
\hline & DSP2 & Torres & Zidane \\
\hline \multirow[t]{2}{*}{ Irrigation level } & $\mathrm{a}$ & $\mathrm{a}$ & $\mathrm{b}$ \\
\hline & dry & regular & wet \\
\hline CMS maize hybrid & $\mathrm{a}$ & $\mathrm{b}$ & $\mathrm{b}$ \\
\hline \multicolumn{4}{|l|}{ Experiment 2} \\
\hline \multirow{3}{*}{ Irrigation level } & DSP2 & Torres & Zidane \\
\hline & $\mathrm{a}$ & $\mathrm{b}$ & c \\
\hline & dry & regular & wet \\
\hline CMS maize hybrid & $\mathrm{ab}$ & $\mathrm{a}$ & $\mathrm{b}$ \\
\hline
\end{tabular}




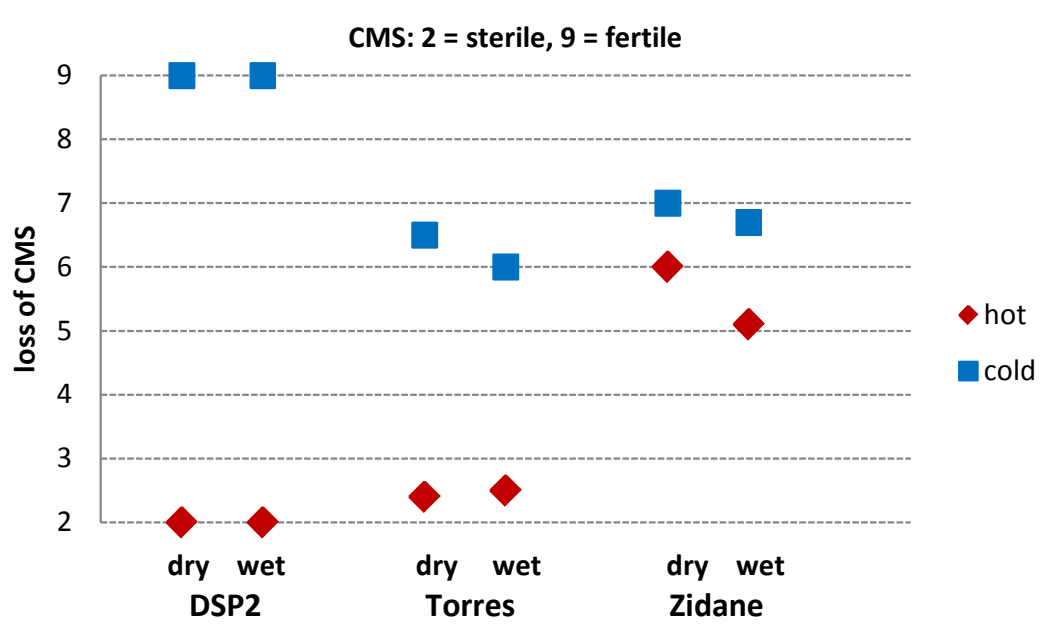

Figure 5. Stability of the sterility trait of three CMS maize hybrids in dependence of air temperature and irrigation levelExperiment 3.

Table 4. Loss of the stability of CMS and standard deviations of three CMS maize hybrids in different air temperature regimes and irrigation levels (dry, wet-Experiment 3).

\begin{tabular}{cccccccc}
\hline & \multicolumn{3}{c}{ DSP2 } & \multicolumn{3}{c}{ Torres } & \multicolumn{2}{c}{ Zidane } \\
\cline { 2 - 7 } Temperature regime & dry & wet & dry & wet & dry & wet \\
\hline cold $\left(21^{\circ} \mathrm{C} / 16^{\circ} \mathrm{C}\right)$ & 9 & 9 & 6.5 & 6 & 7 & 6.7 \\
Standard deviation & 0 & 0 & 0.53 & 0.53 & 0.53 & 0.32 \\
hot $\left(35^{\circ} \mathrm{C} / 22^{\circ} \mathrm{C}\right)$ & 2 & 2 & 2.4 & 2.5 & 6 & 5.1 \\
Standard deviation & 0 & 0 & 0.84 & 0.85 & 0 & 1.37 \\
\hline
\end{tabular}

2 = sterile, 9 = fertile.

of pollen and reached "loss of CMS" values of 6 to 6.5 (Figure 5, Table 4). The level of irrigation did not affect these results. In contrast to Torres and DSP2, Zidane showed partly restored tassels and the production of some pollen (values of 5.1 to 6$)$ in hot air temperatures $\left(22^{\circ} \mathrm{C} / 35^{\circ} \mathrm{C}\right)$. In colder temperatures the "loss of CMS" was higher (value 6.7 to 7) because more tassels of Zidane restored to fertility and produced more pollen compared to "hot" temperature conditions. The irrigation level had no major affect on the tassel and pollen production of Zidane. Experiment 3 showed significant differences of the level of sterility $(p=0.05 \%)$ between the CMS maize hybrids depending on the temperature (Table 5) while the irrigation level resulted in a different level of sterility between Torres and Zidane. Generally, the temperature regime had a significant influence on the level of CMS sterility while the level of irrigation had not.

In experiment 3, the development of kernels after self pollination was measured. Generally, no CMS maize hybrid developed kernels in variant "hot" (Figure 6) but in variant "cold" substantial kernel development occurs. Corresponding to the "loss of CMS" in cold conditions DSP2 plants developed the largest number of kernels per ear (on average 335 in dry and 391 in wet soil) followed by Zidane (on average 226, dry, and 213, wet-Figure 6, Table 6) and Torres (on average 15, dry, and 58, wet). No significant differences of kernel development were measured between "wet" and "dry" but between "hot" and "cold" variants (Table 7). In summary, the level of sterility of the CMS maize hybrids tested was depending on the temperature regime and the extent of the loss of sterility was depending on the genotype.

\section{Discussion}

The objective of this study was to verify whether the irrigation level or soil water availability, the air temperature or the interaction of both can affect the stability of the CMS trait of maize hybrids. The results will help to understand the climatic impacts on the fertility restoration of CMS maize hybrids and to better define conditions 


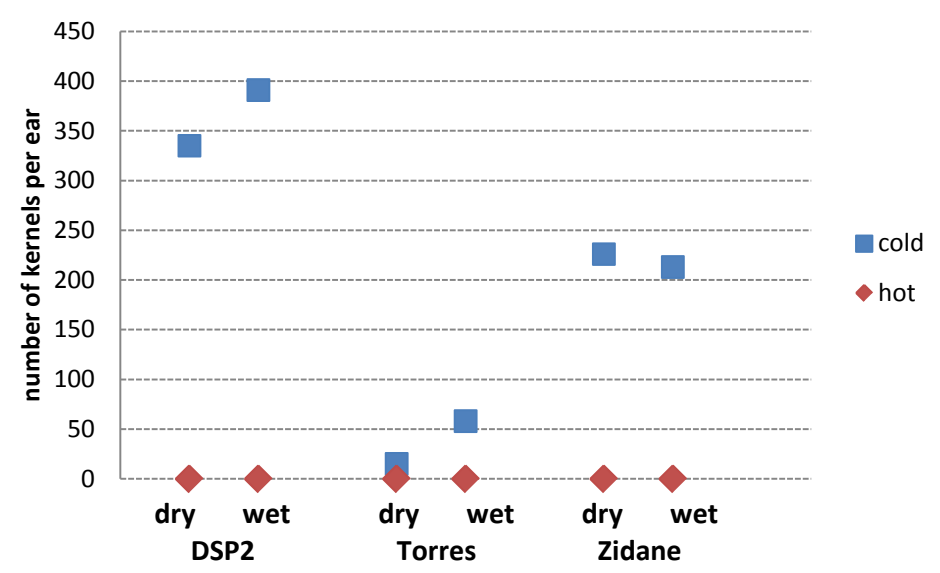

Figure 6. Kernels per ear after self-pollination of three CMS maize hybrids in different air temperature regimes and irrigation levels-Experiment 3.

Table 5. Significance of air temperature, irrigation level and genotype influences on the level of stability of CMS, 2-way anova, $p=0.05$, Experiment 3. Different letters mark significant differences.

\begin{tabular}{|c|c|c|c|}
\hline \multicolumn{4}{|c|}{ Significance level $p=0.05$} \\
\hline & DSP2 & Torres & Zidane \\
\hline \multirow[t]{2}{*}{ Temperature regime } & $\mathrm{a}$ & $\mathrm{b}$ & c \\
\hline & DSP2 & Torres & Zidane \\
\hline \multirow[t]{3}{*}{ Irrigation level } & $\mathrm{a}$ & $\mathrm{ab}$ & ac \\
\hline & hot & cold & \\
\hline & $\left(35^{\circ} \mathrm{C} / 22^{\circ} \mathrm{C}\right)$ & $\left(21^{\circ} \mathrm{C} / 16^{\circ} \mathrm{C}\right)$ & \\
\hline \multirow[t]{2}{*}{ CMS maize hybrid } & a & $\mathrm{b}$ & \\
\hline & dry & wet & \\
\hline CMS maize hybrid & a & a & \\
\hline
\end{tabular}

Table 6. Kernels per ear after self-pollination and standard deviations of three CMS maize hybrids in different air temperature regimes and irrigation levels (dry, wet-Experiment 3).

\begin{tabular}{cccccccc}
\hline \multirow{2}{*}{ Temperature regime } & \multicolumn{2}{c}{ DSP2 } & \multicolumn{2}{c}{ Torres } & \multicolumn{2}{c}{ Zidane } \\
\cline { 2 - 7 } & dry & wet & dry & wet & dry & wet \\
\hline cold $\left(21^{\circ} \mathrm{C} / 16^{\circ} \mathrm{C}\right)$ & 335 & 391 & 15 & 58 & 226 & 213 \\
Standard deviation & 65 & 107 & 17 & 74 & 126 & 141 \\
hot $\left(35^{\circ} \mathrm{C} / 22^{\circ} \mathrm{C}\right)$ & 0 & 0 & 0 & 0 & 0 & 0 \\
Standard deviation & 0 & 0 & 0 & 0 & 0 & 0 \\
\hline
\end{tabular}

Table 7. Significance of air temperature, irrigation level and genotype influences on the amount of kernels produced, 2-way anova, $p=0.05$, Experiment 3. Different letters mark significant differences.

\begin{tabular}{|c|c|c|c|}
\hline \multicolumn{3}{|c|}{ Significance level $p=0.05$} & \multirow{3}{*}{$\begin{array}{c}\text { Zidane } \\
\text { c }\end{array}$} \\
\hline Temperature regime & DSP2 & Torres & \\
\hline & $\mathrm{a}$ & b & \\
\hline \multirow[t]{2}{*}{ Irrigation level } & DSP2 & Torres & Zidane \\
\hline & $\mathrm{a}$ & $\mathrm{b}$ & $\mathrm{a}$ \\
\hline \multirow[t]{3}{*}{ CMS maize hybrid } & hot & cold & \\
\hline & $\left(35^{\circ} \mathrm{C} / 22^{\circ} \mathrm{C}\right)$ & $\left(21^{\circ} \mathrm{C} / 16^{\circ} \mathrm{C}\right)$ & \\
\hline & $\mathrm{a}$ & $\mathrm{b}$ & \\
\hline \multirow[t]{2}{*}{ CMS maize hybrid } & dry & wet & \\
\hline & $\mathrm{a}$ & $\mathrm{a}$ & \\
\hline
\end{tabular}


for the applicability of CMS maize hybrids for coexistence purposes. Therefore, three CMS maize hybrids were cultivated with different irrigation levels and different air temperature regimes in greenhouse conditions.

In all experiments, no significant difference between the levels of sterility developed in different irrigation regimes were observed with the exception of the effect of low irrigation on Zidane. An explanation for this effect might be that the amount of water could have been too low to ensure a sufficient plant development. The expectation that the amount of available soil water affected the stability of the CMS sterility trait following observations in field trials [1] could not be confirmed. In one of these trial years with high precipitation rates, the growth of the maize stands was unequal and partly delayed. Later developed plants (delay of app. 10 days) were detected which blossomed in round about $2^{\circ} \mathrm{C}$ lower temperatures and much more precipitation $(+127 \mathrm{~mm}$ above the longstanding mean for August). The plants developed fertile tassels with a large amount of pollen while most of the earlier flowers of the same hybrid were sterile [1].

Zidane had always a high "loss of CMS" value while Torres had always low "loss of CMS" values which match the findings of Bueckmann et al. (2014) for the same varieties. The sterility level of DSP2 showed sensitivities to the air temperatures. With regard to the temperature curves in the green house cabins of experiment 1 and 2 the plants grew in a temperature environment of average $3^{\circ} \mathrm{C}$ difference. The cooler conditions caused higher "loss of CMS" values of DSP2 while Torres and Zidane were not strongly affected. The results concerning the impact of temperature on the stability of CMS were confirmed in experiment 3 . High air temperatures forced the sterility of all three CMS maize hybrids and low temperatures forced the "loss of CMS". These results circumstantiate the findings of Bueckmann et al. (2014) about the influence of air temperature on the CMS trait which might be explained by the sensitivity of $R f$ gene activation or inactivation to environmental impacts just before and during anthesis [21]. The amount of kernels detected at each ear in experiment 3 matched the "loss of CMS" data: as higher the value of "loss of CMS" as more kernels were produced.

Especially for DSP2 the results of kernel production per cob underline the results found by Bueckmann et al. (2014) and Weider et al. (2009) for the same CMS maize hybrid. The latter authors tested DSP2 among other CMS maize hybrids of the three CMS cytoplasms. DSP2 belongs to the T-cytoplasm which is known as providing-with exceptions - the most reliable male sterility [21]. Restoration to fertility can only happen if two dominant $R f$ genes act together, $R f 1$ and $R f 2$. Solely in the presence of $R f 2$ the $R f 1$ allel affects the transcription of the responsible mitochondrial gene (T-urf13) and causes pollen fertility [23]. The influence of the $R f 1$ gene can be compensated by other dominant $R f$ genes like $R f 8$ [24]. These genes are rarely present in T-cytoplasm types. Their expression is environmentally sensitive and can result in a few fertile or partly restored plants in one population [21] [24]. Obviously, the slight dependency of DSP2 male sterility on weather conditions which is paralleled by pollen dispersal and kernel production is depending on the sporophytic T-cytoplasm as described by Dill et al. (1997). Concerning the kernel production Bueckmann et al. (2014) demonstrated that the kernel development of DSP2 increases with decreasing temperatures occurring shortly before the onset of anthesis (anther and pollen formation).

Torres and Zidane both belong to the CMS S type. This cytoplasm is the most unstable one [25] [26] and the restoration to fertility is more complex compared to the T-cytoplasm. It is probably depending on one dominant and not environment-sensitive restorer gene $(R f 3)$ and a large number of spontaneously occurring $R f$ genes and more than 60 restoring allele mutations [25] [27] [28]). Gabay-Laughnan et al. (2009) [29] identified the Rf9 gene which is stronger expressed under moderate compared to higher temperatures. According to the greenhouse results, an increasing level of $R f 9$ gene expression with decreasing temperatures could be expected for Zidane, resulting in partly restored or fertile tassels and, therefore, a higher "loss of CMS" value. In the case of Torres, the partly restored tassels produced only a very small amount of pollen and reached a low value of "loss of CMS stability”.

Apart from the type of the CMS cytoplasm the influence of the air temperature on the CMS trait was obvious and might be explained by the sensitivity of $r f$ gene activation or inactivation just before anthesis. Weider $e t a l$. (2009) tested twenty two CMS maize hybrids in seventeen environments. They found an influence of climate on CMS restoration, but a clear correlation of climatic parameters and fertility restorations could not be found. This also matches the field trial results of Bueckmann et al. (2013) which were collected in three different German environments in 2009 and 2010. There, a higher level of sterility was measured in 2010, depending on weather conditions: In the first half of July 2010 the average daily air temperatures increased by $3^{\circ} \mathrm{C}$ to $3.5^{\circ} \mathrm{C}$ above the longstanding average temperature at all trial locations. In general, less pollen and, consequently, fewer kernels were produced by all CMS maize hybrids tested. This indicates an influence of air temperature just before an- 
thesis on the restoration of fertility on both T-cytoplasm and S-cytoplasm. Duvick (1956) [30] and Tracy et al. (1991) [31] already assumed that cool and humid conditions cooperate in restoration of fertility, whereas hot and dry conditions maintain sterility. Hot and dry weather causes the development of fewer anthers and pollen can lose its viability or is non-competitive compared with pollen of fertile plants [32].

The influence of high temperatures on the level of sterility was described for other crops as well. Sarvella (1966) described in experiments with cotton that lower temperatures combined with higher humidity were associated with an increased restoration of fertility of CMS plants, but the temperature was the most important factor. Marschall et al. (1974) found that temperatures above $33^{\circ} \mathrm{C}$ were required for the consistent expression of the CMS trait in cotton. This might not only be linked to $R f$ expressions but might be caused by toxin production [33] which affected the CMS trait. Apart from the influence of air temperature on the stability of the CMS trait, other environmental impacts were discussed in the literature, e.g. water limiting conditions for sorghum [34].

CMS is a proven coexistence tool for maize. Cultivation of GM CMS maize hybrids in the frame of coexistence regimes requires an improved knowledge about the influence of the environment on the CMS trait and a sufficient pollination of the GM CMS plants by admixing a male-fertile and non-GM pollen donor [35] [36]. If the CMS maize hybrid and the pollinator plant provide a different genetic background, yield can be significantly increased [37]-[39]. The so-called Plus-Hybrid-Effect [35] [40] combines the potential benefits of CMS and a Xenia effect. CMS hybrids have a "female advantage" over their male-fertile counterparts, which may be caused by increased female fertility related to the reallocation of resources unused in male function or by greater seed vitality by avoiding self-pollination [11]. Hence, when growing GM CMS maize hybrids, pollen containment will be combined with yield increase.

\section{Acknowledgements}

The authors thank the European Commission for funding the PRICE project (Practical Implementation of Coexistence in Europe, http://price-coexistence.com/, FP7/2007-2013, grant agreement No. KBB-2011-5-289157).

\section{References}

[1] Bueckmann, H., Huesken, A. and Schiemann, J. (2013) Applicability of Cytoplasmic Male Sterility (CMS) as a Reliable Biological Confinement Method for the Cultivation of Genetically Modified Maize in Germany. Journal of Agricultural Science and Technology A, 3, 385-403.

[2] Westgate, M., Lizaso, J. and Batchelor, W. (2003) Quantitative Relationship between Pollen-Shed Density and Grain Yield in Maize. Crop Science, 43, 934-942. http://dx.doi.org/10.2135/cropsci2003.9340

[3] Uribelarrea, M., Cárcova, J., Otegui, M. and Westgate, M. (2002) Pollen Production, Pollination Dynamics, and Kernel Set in Maize. Crop Science, 42, 1910-1918. http://dx.doi.org/10.2135/cropsci2002.1910

[4] Poehlmann, J.M. and Sleper, D.A. (1995) Breeding Field Crops. Iowa State University Press, Ames, XV, 494 p.

[5] Brookes, G., Barfoot, P., Melé, E., Messeguer, J., Bénétrix, F., Bloc, D., Foueillassar, X., Fabié, A. and Poeydomenge, C. (2004) Genetically Modified Maize: Pollen Movement and Crop Coexistence. PG Economics Ltd., Dorchester, UK. http://www.pgeconomics.co.uk

[6] Messeguer, J., Peñas, G., Ballester, J., Bas, M., Serra, J. and Salvia, J. (2006) Pollen-Mediated Gene Flow in Maize in Real Situations of Coexistence. Plant Biotechology Journal, 4, 633-645. http://dx.doi.org/10.1111/j.1467-7652.2006.00207.x

[7] Laser, K.D. and Lersten, N.R. (1972) Anatomy and Cytology of Microsporogeneses in Cytoplasmic Male Sterile Angiosperms. The Botanical Review, 38, 425-454. http://dx.doi.org/10.1007/BF02860010

[8] Schnable, P.S. and Wise, R.P. (1998) The Molecular Basis of Cytoplasmic Male Sterility and Fertility Restoration. Trends in Plant Science, 3/5, 175-180. http://dx.doi.org/10.1016/S1360-1385(98)01235-7

[9] Chase, C.D. and Gabay-Laughnan, S. (2004) Cytoplasmic Male Sterility and Fertility Restoration by Nuclear Genes. In: Daniell, H. and Chase, C.D., Eds., Molecular Biology and Biotechnology of Plant Organelles, Springer, New York, 593-622. http://dx.doi.org/10.1007/978-1-4020-3166-3_22

[10] Chase, C.D. (2006) Genetically Engineered Cytoplasmic Male Sterility. Trends in Plant Science, 11, 7-9. http://dx.doi.org/10.1016/j.tplants.2005.11.003

[11] Budar, F., Touzet, P. and De Paepe, R. (2003) The Nucleo-Mitochondrial Conflict in Cytoplasmic Male Sterilities Revisited. Genetica, 117, 3-16. http://dx.doi.org/10.1023/A:1022381016145

[12] Sofi, P.A., Rather, A.G. and Wani, S.A. (2007) Genetic and Molecular Basis of Cytoplasmic Male Sterility in Maize. 
Communications in Biometry Crop Science, 2, 49-60.

[13] Rogers, J.S. and Edwardson, J.R. (1952) The Utilization of Cytoplasmic Male-Sterile Inbreds in the Production of Corn Hybrids. Agronomy Journal, 44, 8-13. http://dx.doi.org/10.2134/agronj1952.00021962004400010004x

[14] Levings, C.S. (1993) Thoughts on Cytoplasmic Male Sterility in cms-T Maize. Plant Cell, 5, 1285-1290. http://dx.doi.org/10.2307/3869781

[15] Jones, D.F., Stinson, H.T.J. and Khoo, U. (1954) Pollen Restoring Genes. Connecticut Agricultural Experiment Station Bulletin, 610, New Haven.

[16] Beckett, J.B. (1971) Classification of Male-Sterile Cytoplasms in Maize. Crop Science, 11, 724-727.

[17] Sarvella, P. (1966) Environmental Influences on Sterility in Cytoplasmic Male-Sterile Cottons. Crop Science, 6, 361364. http://dx.doi.org/10.2135/cropsci1966.0011183X000600040020x

[18] Marshall, D.R., Thomson, N.J., Nicholls, G.H. and Patrick, C.M. (1974) Effects of Temperature and Daylength on Cytoplasmic Male Sterility in Cotton (Gossypium). Australian Journal of Agricultural Research, 25, 443-447. http://dx.doi.org/10.1071/AR9740443

[19] Fan, Z.G. and Stefansson, B.R. (1986) Influence of Temperature on Sterility of 2 Cytoplasmic Male-Sterility Systems in Rape (Brassica napus L.). Canadian Journal of Plant Science, 66, 221-227. http://dx.doi.org/10.4141/cjps86-035

[20] Peterson, C.E. and Foskett, R.L. (1953) Occurrence of Pollen Sterility in Seed Fields of Scott County Globe Onions. Proceedings of the American Society of Horticultural Science, 62, 443-448.

[21] Weider, C., Stamp, P., Christov, N., Hüsken, A., Foueillassar, X., Camp, K.-H. and Munsch, M. (2009) Stability of Cytoplasmic Male Sterility in Maize under Different Environmental Conditions. Crop Science, 49, 77-84. http://dx.doi.org/10.2135/cropsci2007.12.0694

[22] Bueckmann, H., Thiele, K., Huesken, A. and Schiemann, J. (2014) Influence of Air Temperature on the Stability of Cytoplasmic Male Sterility (CMS) in Maize (Zea mays L.). AgBioForum, 17, 205-212

[23] Dewey, R.E, Timothy, D.H. and Levings, C.S. (1987) A Mitochondrial Protein Associated with Cytoplasmic Male Sterility in the T-Cytoplasm of Maize. Proceedings of the National Academy of Science of the United States of America, 84, 5374-5378. http://dx.doi.org/10.1073/pnas.84.15.5374

[24] Dill, C.L., Wise, R. and Schnable, P.S. (1997) Rf8 and Rf* Mediate Unique T-urf13-transcript Accumulation, Revealing a Conserved Motif Associated with RNA Processing and Restoration of Pollen Fertility in T-Cytoplasm Maize. Genetics, 147, 1367-1379.

[25] Gabay-Laughnan, S., Zabala, G. and Laughnan, J.R. (1995) S-Type Cytoplasmic Male Sterility in Maize. In: Levings, C.S. and Vasil, I.K., Eds., The Molecular Biology of Plant Mitochondria, Kluwer Academic Publishers, Dordrecht, 395-432. http://dx.doi.org/10.1007/978-94-011-0163-9_12

[26] Gabay-Laughnan, S., Chase, C.D., Ortega, V.M. and Zhao, L. (2004) Molecular-Genetic Characterization of CMS-S Restorer-of-Fertility Alleles Identified in Mexican Maize and Theosinte. Genetics, 166, 959-970. http://dx.doi.org/10.1534/genetics.166.2.959

[27] Laghnan, J.R. and Gabay, S.J. (1978) Nuclear and Cytoplasmic Mutations to Fertility in S Male-Sterile Maize. In: Walden, D.B., Ed., Maize Breeding and Genetics, John Wiley \& Sons, New York, 427-446.

[28] Gabay-Laughnan, S. (1997) Late Reversion Events Can Mimic Imprinting of Restorer-of-Fertility Genes in CMS-S Maize. Maydica, 42, 163-172.

[29] Gabay-Laughnan, S., Kuzmin, E.V., Monroe, J., Roark, L. and Newton, K.J. (2009) Characterization of a Novel Thermosensitive Restorer of Fertility for Cytoplasmic Male Sterility in Maize. Genetics, 182, 91-103. http://dx.doi.org/10.1534/genetics.108.099895

[30] Duvick, D.N. (1965) Cytoplasmic Pollen Sterility in Corn. Advances in Genetics, 13, 1-56. http://dx.doi.org/10.1016/S0065-2660(08)60046-2

[31] Tracy, W.F., Everett, H.L. and Gracen, V.E. (1991) Inheritance, Environmental Effects and Partial Male Fertility in C-Type CMS in a Maize Inbred. Journal of Heredity, 82, 343-346.

[32] Sotchenko, V., Gorbacheva, A. and Kosogorova, N. (2007) C-Type Cytoplasmic Male Sterility in Corn. Russian Agricultural Sciences, 33, 83-86. http://dx.doi.org/10.3103/S1068367407020048

[33] Sakata, T., Oshino, T., Miura, S., Tomabechi, M., Tsunaga, Y., Higashitani, N., Miyazawa, Y., Takahashi, H., Watanabe, M. and Higashitani, A. (2010) Auxins Reverse Plant Male Sterility Caused by High Temperatures. Proceedings of the National Academy of the United States of America, 107, 8569-8574. http://dx.doi.org/10.1073/pnas.1000869107

[34] Elkonin, L.A., Kozhemyakin, V.V. and Tsvetova, M.I. (2009) Epigenetic Control of the Expression of Fertility-Restoring Genes for the "9E” CMS-Inducing Cytoplasm of Sorghum. Maydica, 54, 243-251.

[35] Feil, B., Weingartner, U. and Stamp, P. (2003) Controlling the Release of Pollen from Genetically Modified Maize and 
Increasing Its Grain Yield by Growing Mixtures of Male-Sterile and Male-Fertile Plants. Euphytica, 130, 163-165. http://dx.doi.org/10.1023/A:1022843504598

[36] Paterniani, E. and Stort, A.C. (1974) Effective Maize Pollen Dispersal in the Field. Euphytica, 23, 129-134. http://dx.doi.org/10.1007/BF00032751

[37] Weingartner, U., Kaeser, O., Long, M. and Stamp, P. (2002) Combining Cytoplasmic Male Sterility and Xenia Increases Grain Yield of Maize Hybrids. Crop Science, 42, 1848-1856. http://dx.doi.org/10.2135/cropsci2002.1848

[38] Munsch, M., Stamp, P., Christoph, N.K., Foueillassar, X., Hüsken, A., Camp, K.-H. and Weider, C. (2010) Grain Yield Increase and Pollen Containment by Plus-Hybrids Could Improve Acceptance of Transgenic Maize. Crop Science, 50, 909-919. http://dx.doi.org/10.2135/cropsci2009.03.0117

[39] Stamp, P., Chowchong, S., Menzi, M., Weingartner, U. and Kaeser, O. (2000) Increase in the Yield of Cytoplasmic Male Sterile Maize Revisited. Crop Science, 40, 1586-1587. http://dx.doi.org/10.2135/cropsci2000.4061586x

[40] Feil, B. and Stamp, P. (2002) The Pollen-Mediated Flow of Transgenes in Maize Can Already Be Controlled by Cytoplasmic Male Sterility. AgBiotechNet, 4. http://www.agbiotechnet.com/Reveiws 